\title{
31. THE DISTRIBUTION OF URANIUM IN OCEANIC ROCKS FROM THE MID-ATLANTIC RIDGE AT $36^{\circ} \mathrm{N}$
}

\author{
W.S. Mitchell and F. Aumento, Department of Geology \\ Dalhousie University, Halifax, Nova Scotia, Canada
}

\begin{abstract}
Several distinct cyclic variations of uranium decreasing with depth through the Leg 37 basalts are described. In any individual cycle, a decrease in uranium is accompanied by a major element decrease in $\mathrm{SiO}_{2}, \mathrm{Al}_{2} \mathrm{O}_{3}, \mathrm{~K}_{2} \mathrm{O}, \mathrm{TiO}_{2}, \mathrm{P}_{2} \mathrm{O}_{5}$, and an increase in the $\mathrm{MgO}$ concentration. The cyclic variations are considered to reflect primary geochemical trends of fractionation of the basaltic magma.

The presence of distinct altered horizons, often at lithological boundaries, where uranium is greatly enriched, complicates and obscures this simple picture of cyclic variation of the element with depth. The distribution of uranium in altered zones of the basalts and in palagonite indicates that in general $\mathrm{U}^{4+}$ appears to be strongly absorbed by oxides and hydroxides of $\mathrm{Fe}^{3+}$.

In fresh basalts and gabbros from Leg 37, concentrations of uranium in primary phenocrysts and fresh glass are, without exception, very low and are comparable to concentrations of the element in the same minerals from peridotite nodules (Nishimura, 1972) and from other oceanic ultramafic rocks (Seitz and Hart, 1973).

Calculated partition coefficients for uranium yield inconsistent results; especially if the uranium concentration in the basaltic matrix is considered representative of the original magmatic abundance of the element. It is clear that coefficients of uranium partition in oceanic rocks are only reliable if calculated for fresh minerals enclosed in totally unaltered sideromelane.
\end{abstract}

\section{INTRODUCTION}

Although uranium is a critical heat-producing element on which estimates of the heat production of the upper oceanic mantle are based, its distribution in oceanic crustal rocks is as yet poorly understood. Cores recovered during the record penetration drilling of oceanic layer 2 on Leg 37 of the Deep Sea Drilling Project therefore provide an excellent opportunity to study in detail the distribution of uranium in several different oceanic rock types.

Uranium in mid-ocean ridge basalts appears to be an extremely sensitive indicator of halmyrolysis; altered basalts are normally found to contain anomalously high concentrations of the element (Aumento, 1971). Several of the Leg 37 drill holes, notably Hole 332B, penetrated deep into the crust with reasonably good core recovery. Thus we had the opportunity to determine whether any variation in uranium with depth through large sections of the core was a primary feature of the basalts or was in fact the result of alteration.

It is well known that during fractional crystallization of a basaltic magma, uranium is strongly partitioned into the residual liquid phase (Rodgers and Adams, 1969). A systematic examination of uranium through a volcanic pile or series of pillow basalts, such as those encountered in the Leg 37 drill holes, should clearly indicate any differentiation trends provided any anomalous uranium values resulting from secondary effects, such as alteration, can be recognized.
For these reasons we made over 300 uranium analyses on powdered whole-rock samples from the five holes drilled on Leg 37.

In addition, the fission track method of mapping uranium was used to establish the effects of halmyrolysis or hydrothermal alteration in the redistribution or enrichment of the element in altered rocks. Uranium distributions were mapped in zones of alteration and in the area of veins or fractures which may have acted as channelways for fluids percolating through the volcanic pile. Fission track maps of the palagonitized glassy rinds so common in several of the Leg 37 drill holes were also used to investigate any changes in uranium distribution that might have taken place during devitrification of sideromelane.

Although trace element partition between rockforming minerals and silicate melts have been utilized to formulate models of basalt genesis (Philpotts and Schnetzler, 1970), little is yet known about the partition of uranium between the crystalline phase and the liquid. Phyric basalts and coarse-grained rocks recovered from Leg 37 were particularly suitable for the determination of uranium concentrations in individual minerals. Measurements of uranium in the matrix surrounding the minerals were used in the calculation of partition coefficients for uranium.

\section{LABORATORY METHODS}

Uranium concentrations in homogenized whole-rock samples of cores recovered from Leg 37 of the Deep Sea 
Drilling Project were determined using the fission track method of analysis (Fisher, 1970). The distribution and concentration of uranium in individual minerals and in zones of alteration were delineated by fission track mapping (Kleeman and Lovering, 1967; Mitchell and Aumento, 1974). The fission track technique of mapping is invaluable because the actual concentration of uranium in the crystal structure of a mineral can be accurately determined. Any possible uranium contamination of a secondary nature occurring along fractures or cleavage planes within the mineral can be readily recognized.

Internal standards were used to monitor the thermal neutron flux to which each sample was exposed. USGS standard rock samples BCR I, DTS I, and W1 were included as unknowns and good agreement was obtained with the standard reference values reported by Flanagan (1973).

\section{HOMOGENIZED WHOLE-ROCK URANIUM VALUES}

Analyses of uranium in whole-rock basalt samples from the Leg 37 drill holes are tabulated in Chapters 25 of this volume. Average uranium concentrations in basalts from Holes 332A, 332B, 333A and Sites 334 and 335 are $0.28 \mathrm{ppm}, 0.19 \mathrm{ppm}, 0.29 \mathrm{ppm}, 0.18 \mathrm{ppm}$, and $0.10 \mathrm{ppm}$, respectively. The spread in average values from 0.18 to $0.29 \mathrm{ppm}$ uranium for all holes except 335 is not considered to reflect any real genetic difference between the basalts occurring in those holes. Instead, since higher concentrations of uranium are expected in altered rocks, the spread is thought to be a function of differing relative proportions of altered and fresh rocks sampled in each hole.

In a study on the interaction of sea water with oceanic layer 2, Aumento et al. (1975) note that uranium is invariably concentrated in basalts that, subject to the effects of halmyrolysis, have become progressively more altered with time. Similarly, Mitchell and Aumento (1976) report that uranium concentrations in basalts recovered from the Nazca plate on Leg 34 of the Deep Sea Drilling Project are generally much higher in the older, more altered basalts.

It is therefore significant that although pillow basalts recovered from Site 335 are considerably older than basalts at the other Leg 37 drill sites (Mitchell and Aumento, this volume), they contain on average only $0.10 \mathrm{ppm}$ uranium, much less than the average concentrations of the element in basalts from any of the other drill holes. Low average uranium concentrations in basalts from Site 335 could easily be explained if the pillow sequence had somehow remained impervious to the fluids of either halmyrolytic or hydrothermal alteration. However, it is unlikely that the permeability of a pillow basalt pile is very low and indeed several investigators have found evidence that the basalts from Site 335 have undergone at least as much if not more alteration than basalts from the other Leg 37 drill holes.

Although major element chemistry indicates that basalts recovered from Site 335 are chemically similar to the basalts drilled at the other sites, it is worth noting that uranium concentrations in the glassy pillow rinds from Site 335 are very low, in the order of $20 \mathrm{ppb}$, much lower than in similar glassy fragments from the other holes (Mitchell and Aumento, this volume). Thus if the uranium content of the quenched basaltic glass represents the original concentration of the element in a parent magma it would appear that the magma extruded as a sequence of pillow basalts in the area of Site 335 may have been relatively depleted in uranium.

The variation of uranium with depth down each hole is shown in Figure 1. Several distinct patterns of uranium distribution in the basalts emerge. For example, in Hole 332B, for which most data are available, there is an abrupt increase in uranium in basalts at 465 meters depth. This enrichment in uranium can be correlated to increase in $\mathrm{CO}_{2}$ (Figure 1), $\mathrm{H}_{2} \mathrm{O}$ TOT and an increased iron oxidation ratio for the same samples. At this depth the basalts are visibly more oxidized and on microscopic examination are obviously altered, the matrix consisting of predominantly devitrified glassy material transected by extensive carbonate-filled fractures. Strong alteration at this depth may be related to fluids percolating along fractures at or near the junction between Units 4 and 5 recognized by the shipboard party at around the 465-meter level. An alternative hypothesis is that a lull in the volcanic activity between Units 5 and 4 may have lasted long enough to allow considerable alteration of the topmost part of Unit 5 by halmyrolysis. Short periods of volcanic quiescence may also have occurred between several other flow units because similar, though less pronounced, effects of uranium enrichment at flow boundaries can be observed. For example, higher than average uranium concentrations occur at the junction between Units 9 and 10 at 637 meters depth in Hole 332B, and between Units 3 and 4 at a depth of 197 meters in Hole 332A.

Apart from those areas of core in which uranium concentrations are clearly related to alteration effects, there are several cycles of uranium decreasing with depth. In Hole $332 \mathrm{~B}$ there is such a cycle between the 630 and 660 meter levels where uranium gradually decreases with depth. In this same section there is a corresponding major element decrease in $\mathrm{SiO}_{2}, \mathrm{Al}_{2} \mathrm{O}_{3}$, $\mathrm{K}_{2} \mathrm{O}$, $\mathrm{TiO}_{2}$, and $\mathrm{P}_{2} \mathrm{O}_{5}$, and an increase in $\mathrm{MgO}$ with depth through the basalts. This probably represents a single magmatic cycle which has resulted in a single differentiated unit or pillow sequence. A similar cyclic chemical variation can be observed between the 320 and 400 meter depths in the same hole. Immediately below 400 meters there is an abrupt decrease in uranium concentrations from an average of $0.23 \mathrm{ppm} \mathrm{U}$ to around $0.12 \mathrm{ppm} \mathrm{U}$. This break occurs between Units 3 and 4 in Hole 332B and indicates that the lavas which built up each of these flow units are quite distinct and probably chemically different.

Within Unit 4 , and in fact several other units, there seems to be a slight decrease in uranium with depth, similar to the cyclic variations of uranium previously described. However, these variations in uranium concentration are for the most part obscured by the effects of alteration which give rise to anomalously high uranium values in altered basalts.

The consistent behavior of uranium in relation to major element variations in these discrete chemical cycles is reflected in plots of uranium against $\mathrm{SiO}_{2}$, 

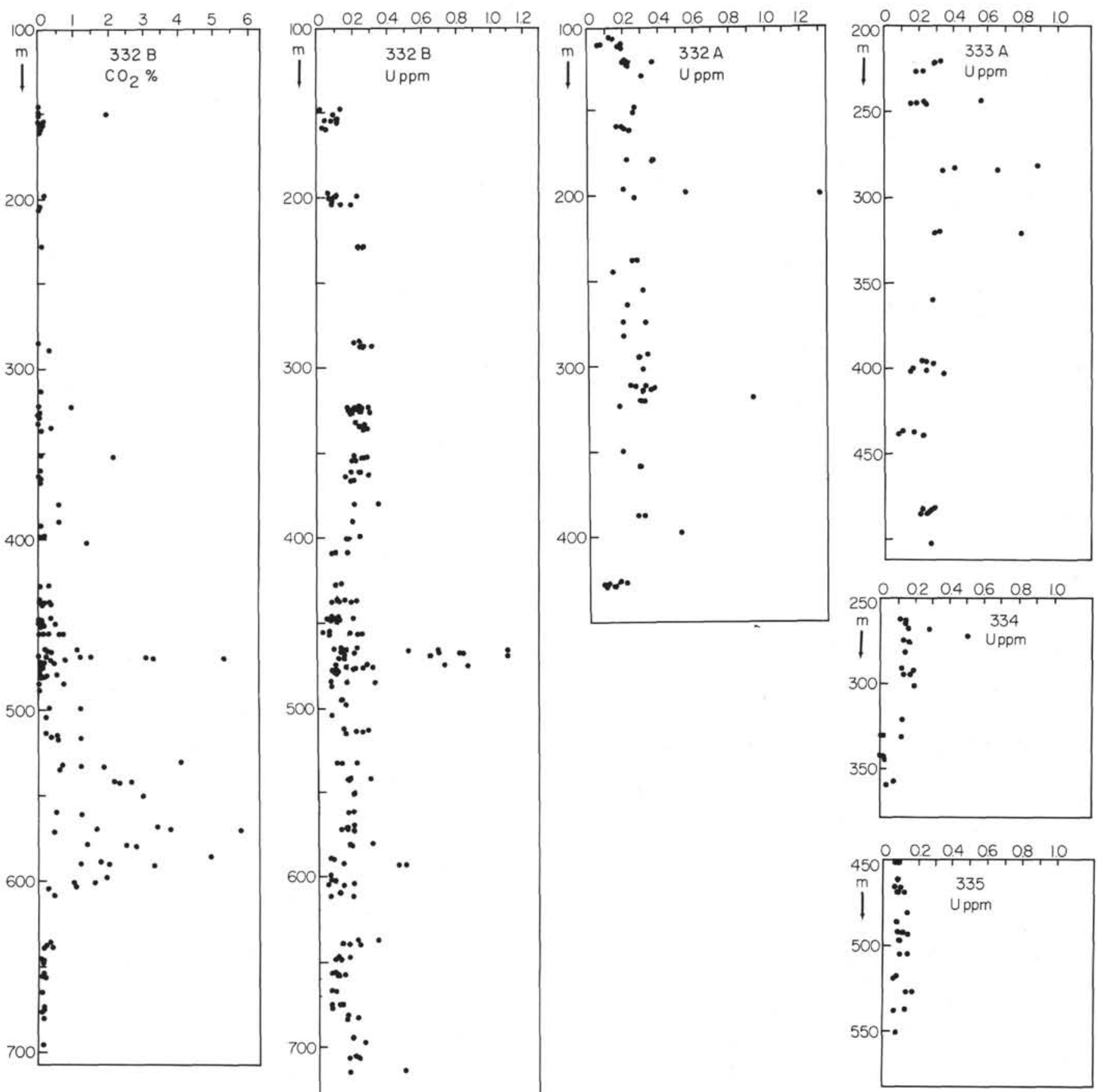

Figure 1. Plot of uranium variation with depth for Leg 37 drill holes.

$\mathrm{K}_{2} \mathrm{O}$, and $\mathrm{MgO}$ for Hole 332B samples (Figures 2, 3, 4). A general trend of uranium increasing with $\mathrm{SiO}_{2}$ can be discerned if anomalous plots resulting from altered samples are discarded. Altered samples are readily recognized by high uranium concentrations in rocks partially depleted in $\mathrm{SiO}_{2}$. The effects of alteration in causing uranium enrichment and $\mathrm{SiO}_{2}$ depletion would therefore tend to mask any primary geochemical trend of $\mathrm{U} / \mathrm{SiO}_{2}$.

An apparently more obvious trend is seen in the $\mathrm{U} / \mathrm{K}_{2} \mathrm{O}$ plot (Figure 3 ). However, since both $\mathrm{U}$ and $\mathrm{K}_{2} \mathrm{O}$ are obviously enriched in altered rocks, any alteration of the samples used in the plot would in this case have the effect of enhancing any primary trend. 


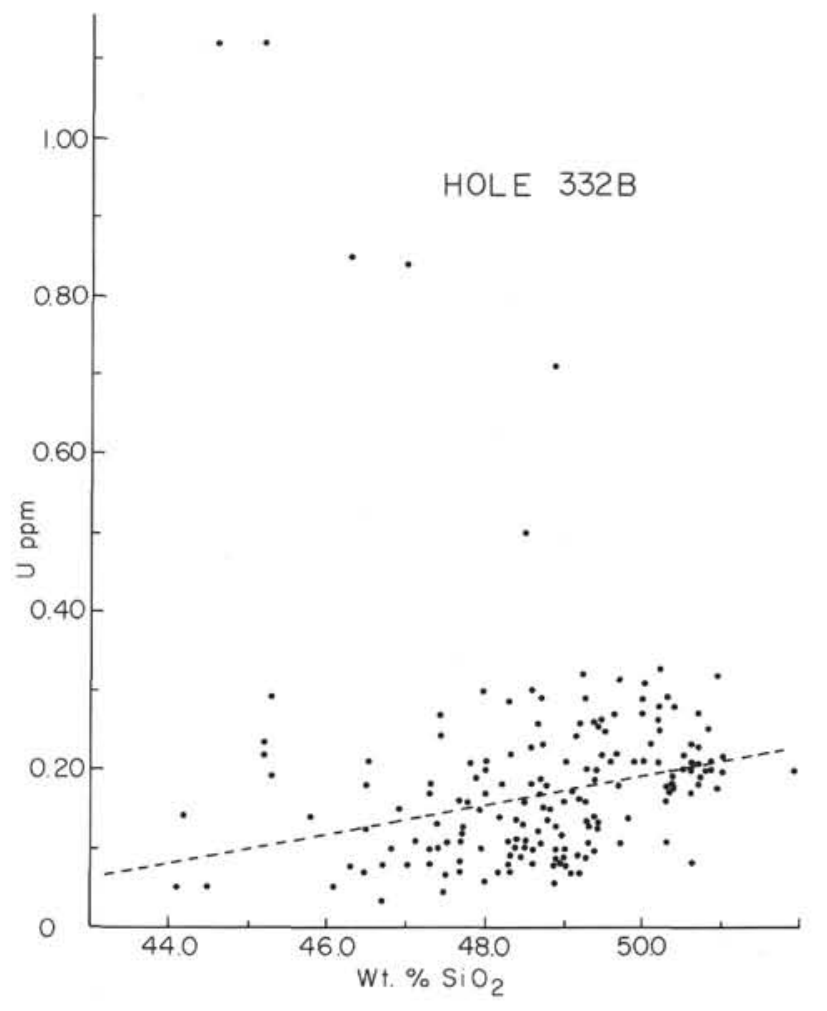

Figure 2. Plot of uranium (ppm) against weight percent $\mathrm{SiO}_{2}$ for Hole 332B. Dashed lines are the least squares regression fit of the data points excluding those from the most altered samples.

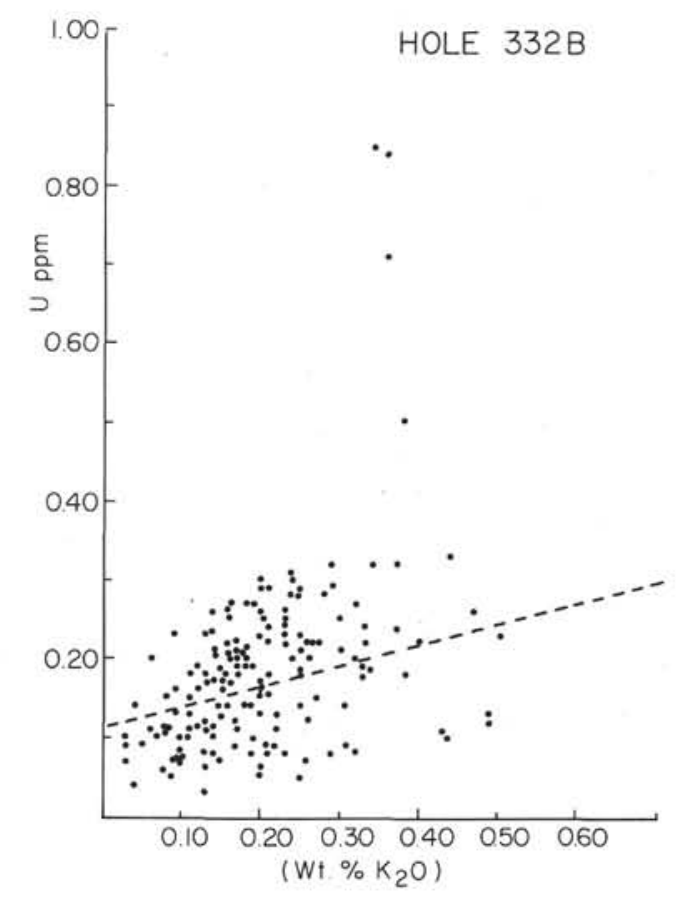

Figure 3. Plot of uranium (ppm) against weight percent $\mathrm{K}_{2} \mathrm{O}$ for Hole 332B. Dashed lines are the least squares regression fit of the data points excluding those from the most altered samples.

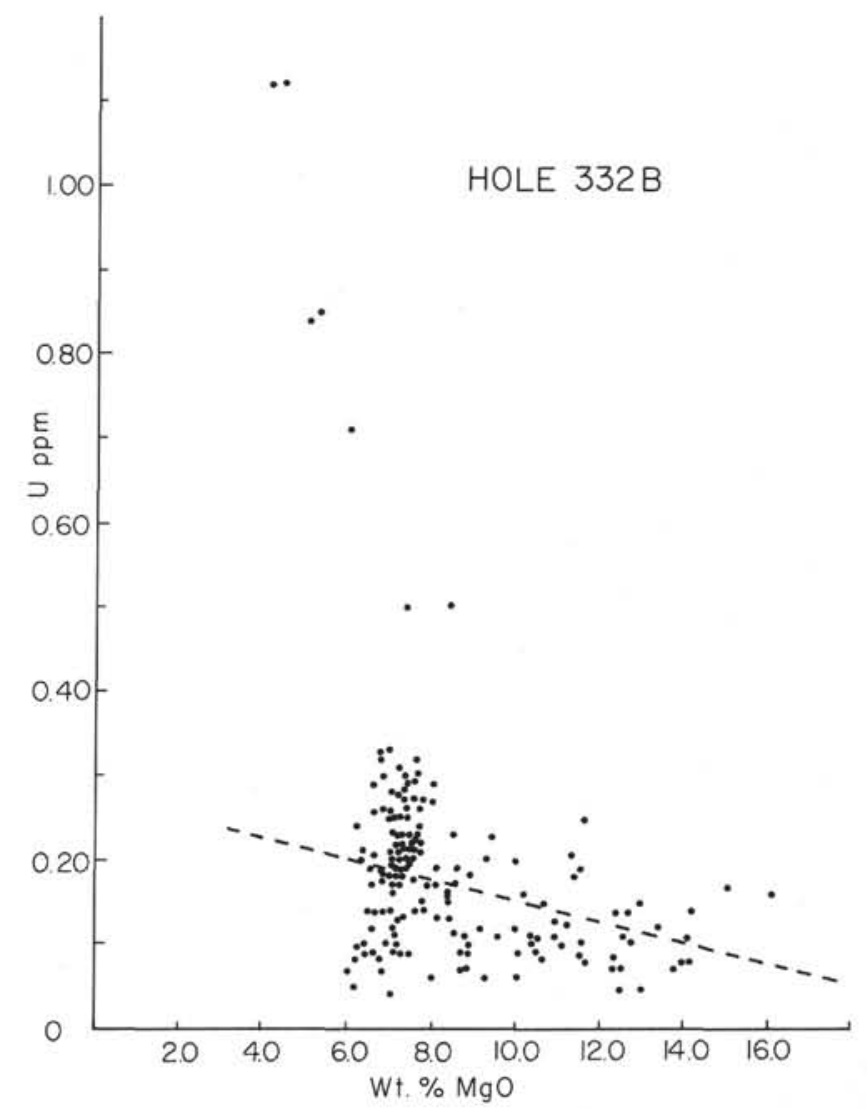

Figure 4. Plot of uranium (ppm) against weight percent $\mathrm{MgO}$ for Hole 332B. Dashed lines are the least squares regression fit of the data points excluding those from the most altered samples.

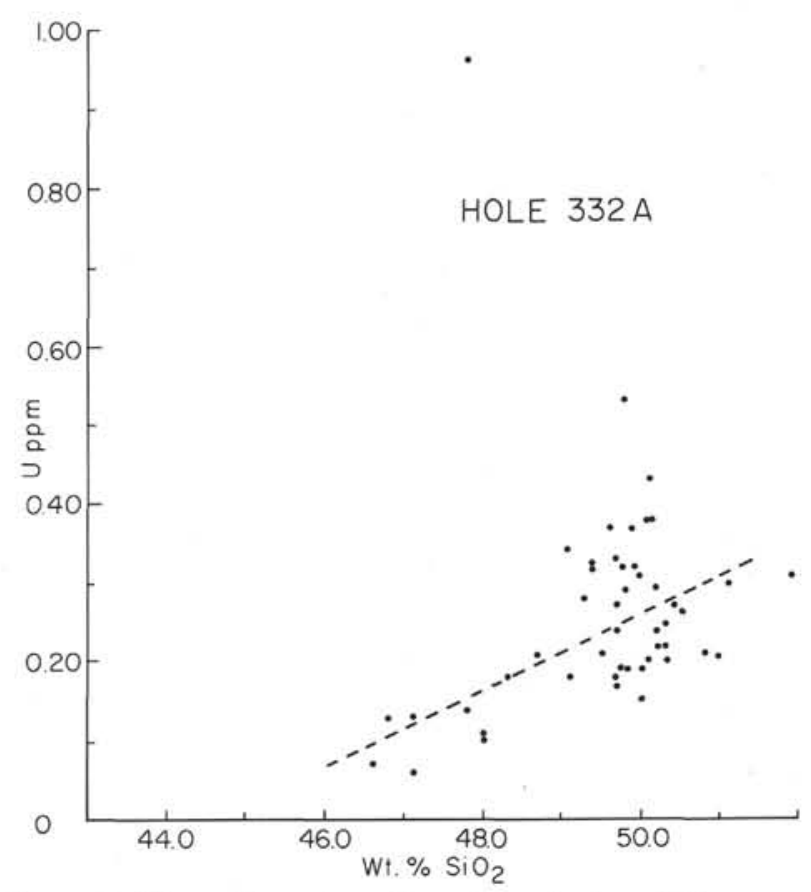

Figure 5. Plot of uranium (ppm) against weight percent $\mathrm{SiO}_{2}$ for Hole 332A. Dashed lines are the least squares regression fit of the data points excluding those from the most altered samples. 
The plot of $\mathrm{U} / \mathrm{MgO}$ (Figure 4) is significant in that both primary and secondary chemical trends can be recognized. The primary trend is of decreasing uranium within increasing $\mathrm{MgO}$, presumably reflecting the same cyclic trend observed in several individual sections of the holes. In these sections increase in $\mathrm{MgO}$ probably results from a general increase in the olivine content of the phyric basalts. Olivine contains only trace amounts of uranium (2.5- $10.5 \mathrm{ppb}$ in Leg 37 samples) and thus any increase in the amount of the mineral present in a basalt would have the effect of diluting and thus lowering the uranium concentration in that rock.

The secondary trend is the result of the effects of alteration on what appears to be virtually undifferentiated basalts. These basalts contain on average around 7 weight percent $\mathrm{MgO}$, but exhibit a considerable uranium variation which is directly related to the various degrees of alteration of the rocks.

Uranium cycles of the type observed in Hole 332B are not so obvious in Hole $332 \mathrm{~A}$ even though it was drilled only 106 meters northwest of Hole 332B, and the only possible correlation in uranium values between the two holes is at a depth of 430 meters where corresponding low uranium values are observed. This correlation seems justified because, at this depth in Hole 332B, olivine settling units are noted in the core log while at the same depth in Hole 332A phyric basalts containing olivine are also present.

Plots of uranium against $\mathrm{SiO}_{2}, \mathrm{~K}_{2} \mathrm{O}$, and $\mathrm{MgO}$ for basalts analyzed from Hole $332 \mathrm{~A}$ are shown in Figures 5,6 , and 7 . Bearing in mind the smaller amount of data available, trends similar to those observed in Hole 332B are apparent. These matching trends indicate that although there appears to be little correlation of lithological units between the two holes, the magmas which built up the volcanic units in each hole were alike in character and underwent similar crystallization differentiation.

On account of poor core recovery for Hole 333A (approximately $8 \%$ of the drilled section) and because the depth of the recovered samples is only an estimate based on drilling effort, the plot of uranium against depth must be considered only approximate. It would therefore be fruitless to attempt to discern any geochemical trends.

Hole 334 penetrated coarse-grained rocks at around 310 meters depth subbottom. This change from a predominantly basaltic sequence to coarse-grained mafic and ultramafic rocks is reflected in the sudden decrease in whole-rock uranium concentrations below 310 meters (Figure 1). Insufficient major element analyses for the basalts from Site 334 were available for any meaningful plotting of their uranium variation.

Uranium at Site 335 shows no obvious variation with depth (Figure 1), reflecting the chemical uniformity of the basalts recovered from this hole. The shipboard party recognized that these basalts belong to a single uniform pillow sequence. There is no concomitant increase of uranium and $\mathrm{SiO}_{2}$ (Figure 8), and only a slight trend of uranium enrichment with increased $\mathrm{K}_{2} \mathrm{O}$ is observed (Figure 9). A slight trend of increasing $\mathrm{MgO}$ with decreasing $U$ (Figure 10) is believed to reflect only minor variations in olivine content of the rocks.

\section{URANIUM IN ZONES OF ALTERATION}

Whole-rock uranium analyses of Leg 37 basalts have already shown that there is a strong correlation between anomalously high uranium concentrations and obvious zones of alteration and that primary trends of uranium fractionation are partly obscured by the effects of alteration.

In order to examine the nature of uranium enrichment in these altered zones, we mapped variations in the distribution of the element between fresh and altered zones in the basalts. Alteration of the basalts increases progressively with proximity to fractures and is often recognized easily by the increased intensity of iron oxide stain in highly altered areas. Fission track maps covering several altered zones clearly indicate that track densities which are directly proportional to the uranium concentration, increase progressively towards the more oxidized basaltic matrix bordering fractures and veins. $\mathrm{U}^{4+}$ therefore appears to be strongly absorbed by oxides of $\mathrm{Fe}^{3+}$, resulting in relatively high uranium concentrations in oxidized zones (Tables 1 and 2).

Changes in uranium distribution between sideromelane and palagonitized zones were also examined by fission track mapping. In most of the glassy pillow rinds examined the transformation from sideromelane to yellowish-brown palagonite is accompanied by a large uranium increase in the altered material (Table 1). In fact, uranium is considerably enriched even in glass which is only slightly devitrified.

The effect of uranium enrichment in palagonitized glass is best demonstrated in a series of photographic plates of fission track maps (Plates 1-4). Fission tracks formed by uranium fission fragments impinging on the detector are seen as black spots on the fission track photographs. Each photograph of a fission track map can be directly compared to the accompanying photograph of the thin rock slice from which the specific map was made. Except for one small rounded plagioclase phenocryst, Plate 1 is a fission track map of almost totally glassy basaltic rind. Increased concentrations of uranium in the palagonitized zones which surround individual glass fragments are readily seen.

A similar example is seen in Plate 2. In this case the palagonitized glassy rind is in contact with baked nanno ooze. Again uranium is concentrated in the zones of yellow-brown palagonite surrounding sideromelane fragments and in a relatively wide zone of dark brown palagonite at the contact between the sediment and the basalt. In this illustration the uniform distribution of uranium in the baked sediment can also be seen, there being no obvious concentration of the element at the contact with the devitrified pillow rind.

Plate 3 shows large plagioclase phenocrysts set in a fractured and palagonitized glassy matrix. Again low uranium concentrations are observed in fresh basaltic glass whereas zones of palagonite, as expected, are rich in uranium.

In Plate 4 the detector sheet was photographed in register with the rock slice as used during quantitative fission track mapping of uranium. Sideromelane visible at the center of the plate contains very little uranium $(47 \mathrm{ppb})$ whereas the devitrified glassy material sur- 


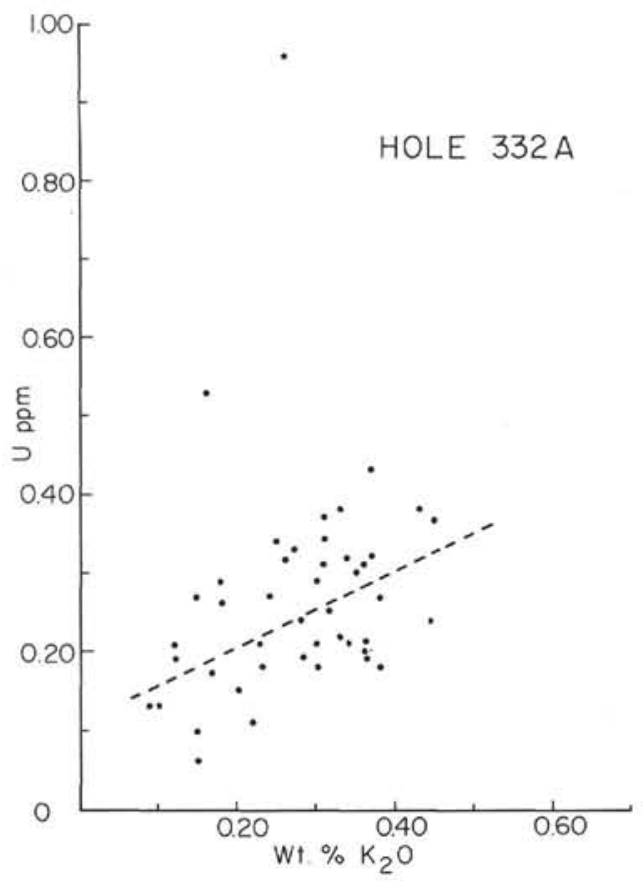

Figure 6. Plot of uranium (ppm) against weight percent $\mathrm{SiO}_{2}$ and $\mathrm{K}_{2} \mathrm{O}$ for Hole 332A. Dashed lines are the least squares regression fit of the data points excluding those from the most altered samples.

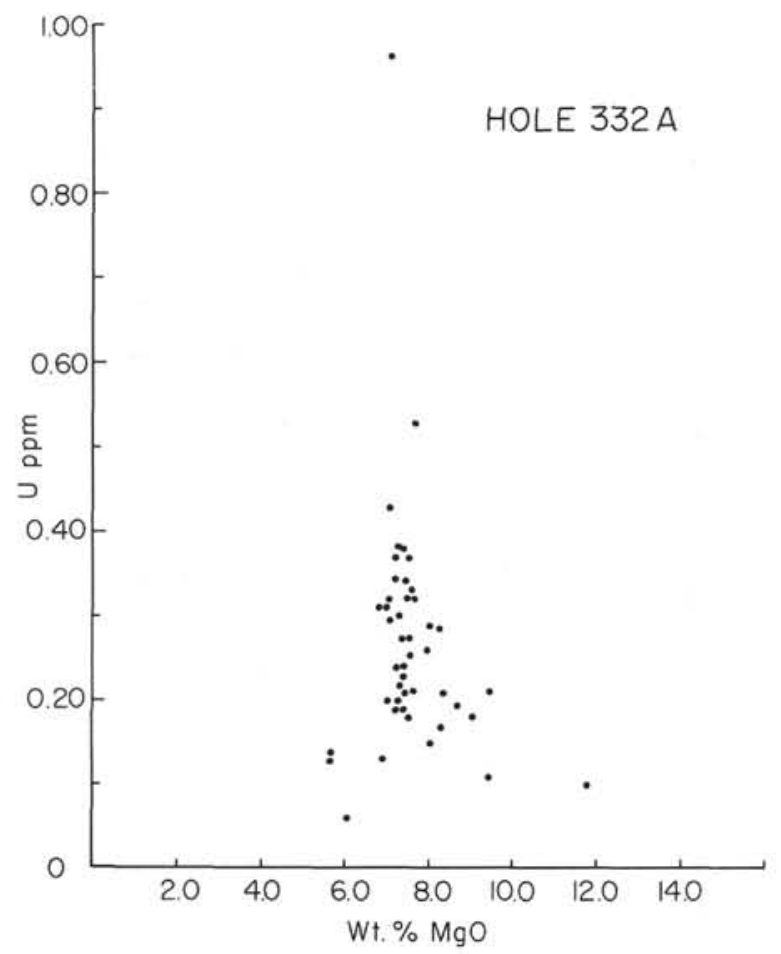

Figure 7. Plot of uranium (ppm) against weight percent $\mathrm{MgO}$ for Hole 332A. Dashed lines are the least squares regression fit of the data points excluding those from the most altered samples.

rounding the fresh basaltic glass contains approximately $770 \mathrm{ppb}$ uranium. Clearly the formation of palagonite by hydration or oxidation of sideromelane is accompanied by significant uranium enrichment.

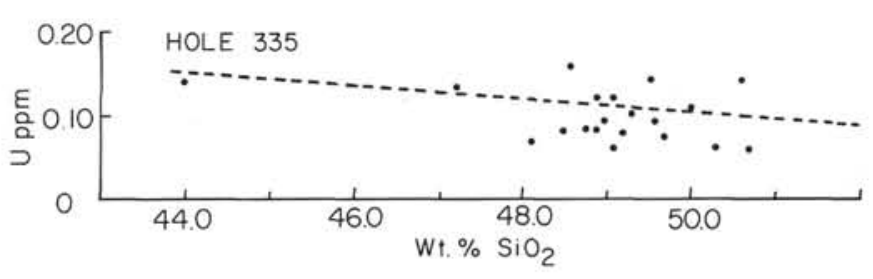

Figure 8. Plot of uranium (ppm) against weight percent $\mathrm{SiO}_{2}$ for Site 335. Dashed lines are the least squares regression fit of the data points excluding those from the most altered samples.

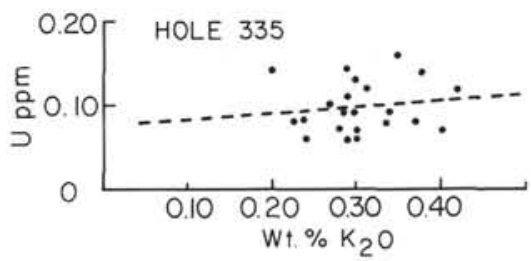

Figure 9. Plot of uranium (ppm) against weight percent $\mathrm{K}_{2} \mathrm{O}$ for Site 335. Dashed lines are the least squares regression fit of the data points excluding those from the most altered samples.

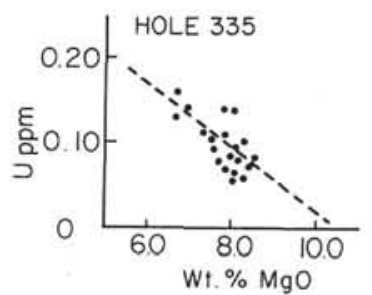

Figure 10. Plot of uranium ( $\mathrm{ppm})$ against weight percent $\mathrm{K}_{2} \mathrm{O}$ for Site 335. Dashed lines are the least squares regression fit of the data points excluding those from the most altered samples.

\section{URANIUM IN MINERAL PHASES}

One of the main advantages in using fission track techniques to determine the amount of uranium in an individual mineral is that any uranium contamination in the crystal can be recognized easily. In Plate 2, for example, a small group of fission tracks can be seen in the detector in the area corresponding to the lower right of the large plagioclase phenocryst. The fission tracks coincide with a fracture in the plagioclase at this point and are obviously the result of uranium contamination along the fracture. Cleavage planes can also contain uranium impurities and if the detector illustrated in Plate 3 is superimposed in register on the rock slice, several fission tracks can be seen to lie along welldeveloped cleavage planes.

Results of fission track analyses of uranium in constituent mineral phases of phyric basalts, gabbros, and lherzolites are presented in Table 2. In general we found that fresh minerals in which no uranium contamination has occurred contain very low concentrations of the element. In contrast, altered matrix, devitrified glass, various oxides, and serpentine minerals contain most of 
TABLE 1

Uranium Concentrations (ppb) in Glassy Pillow Rinds, Altered Zones, and Baked Sediments

\begin{tabular}{lccccc}
\hline $\begin{array}{c}\text { Sample } \\
\text { (Interval in cm) }\end{array}$ & Sideromelane & Palagonite & $\begin{array}{c}\text { Plagioclase } \\
\text { in Glass }\end{array}$ & $\begin{array}{c}\text { Oxidized } \\
\text { Zones }\end{array}$ & $\begin{array}{c}\text { Baked } \\
\text { Sediment }\end{array}$ \\
\hline $\begin{array}{l}332 \mathrm{~B}-36-2, \\
102-112(\# 4 \mathrm{~A})\end{array}$ & 68.9 & 1960 & 9.0 & & \\
$\begin{array}{l}332 \mathrm{~B}-36-2, \\
20-25(\# 1)\end{array}$ & 83.0 & 1860 & 10.7 & 2590 & 240.0 \\
$\begin{array}{l}332 \mathrm{~B}-45-1, \\
80-83\end{array}$ & $190^{\mathrm{a}}$ & & 6.2 & & \\
$\begin{array}{l}333 \mathrm{~A}-8-3, \\
32(\# 4)\end{array}$ & $230^{\mathrm{a}}$ & 240 & & & \\
$\begin{array}{l}335-6-6, \\
22-24(\# 2)\end{array}$ & 23.0 & 55.0 & & 1054 & 157.0 \\
$\begin{array}{l}335-7-2, \\
70-72(\# 5 \mathrm{~B})\end{array}$ & 28.0 & 214.0 & & & \\
$\begin{array}{l}335-7-2, \\
\begin{array}{l}141-143(\# 10) \\
335-9-3,\end{array}\end{array}$ & 19.0 & 585.0 & & 1780 & \\
$\begin{array}{l}14-17(\# 2 \mathrm{~A}) \\
335-9-5,\end{array}$ & 25.0 & 250.0 & & & 130.0 \\
$46-48(\# 5)$ & 49.0 & 154.0 & & & 114.0 \\
\hline
\end{tabular}

${ }^{\text {a} P a r t i a l l y ~ d e v i t r i f i e d ~ g l a s s . ~}$

the uranium in oceanic rocks, and it is again evident that $\mathrm{U}^{4+}$ is absorbed by hydroxides and oxides of $\mathrm{Fe}^{3+}$. The very low concentrations of uranium in minerals is well illustrated in Plate 5 in which the detector has been photographed in correct register on the rock slice. Fission tracks are virtually absent in the light areas which are plagioclase phenocrysts, but are numerous in the dark areas of devitrified matrix which is relatively rich in uranium. In this case the uranium concentration of the plagioclase is $9.0 \mathrm{ppb}$, this figure resulting from track counts over the total area of the crystals of which only small parts are shown in the photographs.

Values of uranium in olivine and clinopyroxene from the Leg 37 rocks are comparable to those reported for the same minerals from peridotite nodules (Nishimura, 1972). Concentrations of uranium in olivine, plagioclase, and clinopyroxene are virtually identical to the values obtained for uranium in equivalent minerals from the Rhum layered igneous complex (Henderson et al., 1971). Seitz and Hart (1973) also report similar uranium concentrations in minerals from oceanic ultramafic rocks.

Uranium concentrations in fresh minerals in the phyric basalts show the following range in value: olivine, 3.5-10.5 ppb; plagioclase, 7.4-13.0 ppb; clinopyroxene, $42 \mathrm{ppb}$. The same minerals in the gabbros and lherzolites as a rule contain slightly lower concentrations of the element, as follows: olivine, 2.5-3.0 $\mathrm{ppb}$; plagioclase, 6.8-8.2 ppb; clinopyroxene, 10-17.9 ppb.

Clinopyroxene in both the basalts and coarse-grained rocks consistently exhibits higher uranium values than does plagioclase. In turn, plagioclase contains at least double the amount of uranium found in co-existing olivine.

This consistent pattern of uranium partition between these minerals can probably be explained on the basis of the work by Onuma et al. (1968) on the relationships between trace element partition coefficients, ionic radius, valency, and structural sites available for substitution by a particular trace element. They concluded that the elements that can best fit into a particular structural site are of similar ionic radii regardless of charge. Thus in clinopyroxene $\mathrm{U}^{4+}$ would relatively easily occupy the large M1 site whereas in the olivine structure $\mathrm{U}^{4+}$ would only with difficulty occupy the small octahedral site occupied normally by $\mathrm{Mg}^{2+}$ and $\mathrm{Fe}^{2+}$.

\section{PARTITION COEFFICIENTS FOR URANIUM}

The theory and application of trace element partition coefficients to geology has been reviewed by McIntire (1963). Problems and assumptions involved in the calculation of partition coefficients have been discussed by Philpotts and Schnetzler (1970) and by Albarede and Bottinga (1972).

Bearing these considerations in mind, we calculated partition coefficients for uranium between minerals in Leg 37 basalts and the parent magma, using values of uranium in the matrix as evidence of the trace element concentration in the melt. Partition coefficients for uranium were also calculated for several phenocrysts completely enclosed in basaltic glass, which, being rapidly quenched magma, should reflect the original uranium values in the melt unless subsequent diffusion or devitrification has occurred. Simple partition coefficients (D) were calculated as the ratio between the concentration of uranium in the crystalline phase and the concentration of the element in the melt. Partition coefficients were calculated using uranium values given in Tables 1 and 2 and are presented in Table 3.

Partition coefficients of uranium calculated for plagioclase in glassy basaltic matrix gave two consistent results of 0.13 . Plagioclase in normal microcrystalline 
TABLE 2

Uranium Concentrations (ppb) in Constituent Mineral Phases of Basalts and Ultramafic Rocks

\begin{tabular}{|c|c|c|c|c|c|c|c|c|c|}
\hline $\begin{array}{l}\text { Sample } \\
\text { (Interval } \\
\text { in } \mathrm{cm} \text { ) }\end{array}$ & Rock Type & $\begin{array}{l}\text { Aug. } \\
\text { Rock } \\
\text { Slice }\end{array}$ & Matrix & Plagioclase & Olivine & $\begin{array}{l}\text { Clino- } \\
\text { pyroxene }\end{array}$ & Serpentine & Spinel & $\begin{array}{l}\text { Oxidized } \\
\text { Zones/ } \\
\text { Veins }\end{array}$ \\
\hline $\begin{array}{l}332 \mathrm{~B}-3-4, \\
20(\# 1) \\
332 \mathrm{~B}-3-4\end{array}$ & $\begin{array}{l}\text { Olivine, plagioclase } \\
\text { phyric basalt } \\
\text { Plagioclase phyric }\end{array}$ & 43.0 & 78.0 & 11.6 & 3.5 & & & & \\
\hline $59(\# 2 B)$ & basalt & 41.0 & 178 & $\begin{array}{c}7.4 \\
(24.0)^{\mathrm{a}}\end{array}$ & & & & & \\
\hline $\begin{array}{l}332 \mathrm{~B}-19-1 \\
10-19(\# 2)\end{array}$ & $\begin{array}{l}\text { Olivine phyric } \\
\text { basalt }\end{array}$ & 126 & 200 & & 10.0 & & 560 & & \\
\hline $332 \mathrm{~B}-19-1$ & Olivine phyric & & & & & & & & \\
\hline $75-78(\# 8 A)$ & basalt & 140 & 177 & & 6.0 & & 210 & & \\
\hline $332 \mathrm{~B}-21-1$, & Olivine phyric & & & & & & & & \\
\hline $93-96(\# 7 \mathrm{~A})$ & basalt & 190 & 96.0 & & 10.5 & & 322 & 3.0 & 550 \\
\hline $\begin{array}{l}332 \mathrm{~B}-44-1, \\
47-49(\# 3 \mathrm{C})\end{array}$ & $\begin{array}{l}\text { Plagioclase phyric } \\
\text { basalt }\end{array}$ & 144.5 & 230 & $\begin{array}{c}8.5 \\
(11.3)^{\mathrm{a}}\end{array}$ & & & & & \\
\hline $\begin{array}{l}333 \mathrm{~A}-10-3, \\
59-62(\# 16)\end{array}$ & $\begin{array}{l}\text { Plagioclase olivine } \\
\text { phyric basalt }\end{array}$ & 240 & 198 & $\begin{array}{c}9.0 \\
(11.5)^{\mathrm{a}}\end{array}$ & 4.0 & 42.0 & & & 260 \\
\hline $334-22-1$, & Gabbro & & & & & & & & \\
\hline $17-23(\# 3 C)$ & & 31.0 & & 3.3 & & 150 & & & \\
\hline $334-22-2$ & Serpentinized & & & & & & & & \\
\hline $\begin{array}{l}80-82 \text { (\#6B) } \\
334-23-1\end{array}$ & lherzolite & 17.3 & & & 2.8 & 11.6 & 36.5 & & \\
\hline $\begin{array}{l}334-23-1, \\
46-54\end{array}$ & $\begin{array}{l}\text { Serpentinized } \\
\text { lherzolite }\end{array}$ & 330 & & & & & 330 & & \\
\hline $\begin{array}{l}334-24-2, \\
105-107\end{array}$ & Olivine gabbro & & & & & & & & \\
\hline$(\# 10 \mathrm{~B})$ & & 13.5 & & 8.2 & 3.0 & 17.9 & 15.1 & & \\
\hline $\begin{array}{l}334-26-1, \\
70-75(\# 10)\end{array}$ & $\begin{array}{l}\text { Serpentinized } \\
\text { lherzolite }\end{array}$ & 88 & & & & $50^{\mathrm{b}}$ & 170 & & \\
\hline $334-26-2$ & Olivine gabbro & & & & & & & & \\
\hline $56-71(\# 8)$ & & 6.0 & & $6.8^{\mathrm{c}}$ & 2.5 & 10.0 & 13.8 & & \\
\hline $\begin{array}{l}335-9-5, \\
15-17(\# 2)\end{array}$ & $\begin{array}{l}\text { Plagioclase phyric } \\
\text { basalt }\end{array}$ & 103 & 92.0 & $\begin{array}{l}13.0 \\
(22.0)^{\mathrm{a}}\end{array}$ & & & & & \\
\hline $\begin{array}{l}335-10-2, \\
17-19 \text { (\#1B) }\end{array}$ & $\begin{array}{l}\text { Plagioclase phyric } \\
\text { basalt }\end{array}$ & 78 & 117 & $\begin{array}{c}8.0 \\
(26.0)^{\mathrm{a}}\end{array}$ & & & & & 69 \\
\hline $\begin{array}{l}335-12-3, \\
138-140\end{array}$ & $\begin{array}{l}\text { Plagioclase phyric } \\
\text { basalt }\end{array}$ & & & & & & & & \\
\hline$(\# 7 B)$ & & 59 & 42 & 11.5 & & & & & \\
\hline
\end{tabular}

${ }^{a}$ Figures in parentheses refer to the uranium concentration in fractures within plagioclase.

${ }^{\mathrm{b}}$ Clinoamphibole replacing clinopyroxene plagioclase composition An 70 .

CPlagioclase composition An 70.

basaltic matrix gave a wide range of partition coefficients from 0.03 to 0.15 . Two of these partition coefficients are similar to those obtained using the glassy matrix, but the others are much lower.

The dichotomy in the determined partition coefficients for uranium in plagioclase is a probable effect of alteration which, as previously demonstrated, can cause considerable secondary uranium enrichment in matrix material, especially if it contains devitrified glass. Phenocrysts in the basalts are less susceptible than matrix to the effects of alteration, and therefore it becomes immediately obvious that unless partition coefficients for uranium are determined in completely fresh rocks, the calculated values will be erroneously low. There is evidence from fission track chronology of Leg 37 basaltic glasses (Mitchell and Aumento, this volume) that uranium concentrations in fresh sideromelane have remained virtually unchanged since the magma was quenched. Therefore partition coefficients of uranium calculated for minerals enclosed in sideromelane are more likely to reflect the true ratios of uranium partitioned between a mineral and coexisting melt.

Uranium partition coefficients for olivine range from 0.03 to 0.11 , the reliability of the data being subject to the same considerations noted previously for plagioclase.

\section{CONCLUSIONS}

Whole-rock uranium concentrations in Leg 37 basalts indicate that there are several distinct magmatic 
TABLE 3

Partition Coefficients (D) for

Uranium in Plagioclase and Olivine

\begin{tabular}{|c|c|c|}
\hline $\begin{array}{c}\text { Sample } \\
\text { (Interval in } \mathrm{cm} \text { ) }\end{array}$ & D Plagioclase & D Olivine \\
\hline $\begin{array}{l}332 \mathrm{~B}-3-4, \\
20(\# 1)\end{array}$ & 0.15 & 0.04 \\
\hline $\begin{array}{l}332 \mathrm{~B}-3-4, \\
59(\# 2 \mathrm{~B})\end{array}$ & 0.04 & \\
\hline $\begin{array}{l}332 \mathrm{~B}-19-1 \text {, } \\
10-19(\# 2)\end{array}$ & & 0.05 \\
\hline $\begin{array}{l}332 \mathrm{~B}-19-1, \\
75-78(\# 8 \AA)\end{array}$ & & 0.03 \\
\hline $\begin{array}{l}332 \mathrm{~B}-21-1, \\
18-21(\# 1 \mathrm{~A})\end{array}$ & & 0.06 \\
\hline $\begin{array}{l}332 \mathrm{~B}-21-1, \\
93-96(\# 7 \mathrm{~A})\end{array}$ & & 0.11 \\
\hline $\begin{array}{l}332 \mathrm{~B}-44-1, \\
47-49(\# 3 \mathrm{C})\end{array}$ & 0.04 & \\
\hline $\begin{array}{l}333 \mathrm{~A}-10-3, \\
59-62(\# 16)\end{array}$ & 0.05 & 0.05 \\
\hline $\begin{array}{l}335-9-5, \\
15-17(\# 2)\end{array}$ & 0.14 & \\
\hline $\begin{array}{l}335-10-2, \\
17-19(\# 1 B)\end{array}$ & 0.07 & \\
\hline $\begin{array}{l}335-12-3, \\
138-140 \text { (\#7B) }\end{array}$ & 0.03 & \\
\hline $\begin{array}{l}332 \mathrm{~B}-36-2, \\
102-112(\# 4 \mathrm{~A})\end{array}$ & $0.13^{\mathrm{a}}$ & \\
\hline $\begin{array}{l}\text { 332B-36-3, } \\
20-25(\# 1)\end{array}$ & $0.13^{\mathrm{a}}$ & \\
\hline
\end{tabular}

cycles of uranium variation with depth down several of the drill holes. Uranium cycles are most obvious in Hole 332B for which most data are available, and are considered to reflect primary geochemical trends of the element during fractionation of the basaltic magma. Primary trends of uranium variation within the basalts are, to some extent, obscured by a secondary trend of uranium enrichment related solely to alteration.

In altered basalts secondary uranium is preferentially concentrated in highly altered zones, in oxidized areas, and in vein or fracture infilling material. In general $\mathrm{U}^{4+}$ shows a strong affinity for oxides of $\mathrm{Fe}^{3+}$. Devitrified glassy matrix and palagonite rims surrounding sideromelane are enriched in uranium by several orders of magnitude relative to fresh glass. There appears to be no systematic decrease in alteration with depth through the basalts, but zones of highly altered basalt commonly occur at flow tops that, during a hiatus in volcanic activity, were exposed to halmyrolysis.

Uranium concentrations in constituent mineral phases in both basalts and coarse-grained rocks remain reasonably constant for the same minerals provided they are not altered. In general, clinopyroxene contains more uranium than does plagioclase or olivine. Likewise, concentrations of uranium in plagioclase are almost double the amount found in coexisting olivine.

Partition of uranium between individual minerals appears to remain reasonably constant. Good agreement is obtained between calculated uranium partition coefficients for minerals enclosed in sideromelane, but for minerals set in a crystalline basaltic matrix, partition coefficients for the element are more variable and anomalously low values can be attributed to the effects of alteration. This further problem in determining partition coefficients has obvious and important implications for future trace element partition coefficient studies in oceanic rocks.

\section{ACKNOWLEDGMENTS}

Financial support for the laboratory work was provided by the National Research Council of Canada. We are indebted to Tim Milligan for preparation of samples for whole-rock uranium analyses and to Keith Taylor for the preparation of diagrams and photographs.

\section{REFERENCES}

Albarede, F. and Bottinga, Y., 1972. Kinetic disequilibrium in trace element partitioning between phenocrysts and host lava: Geochim. Cosmochim. Acta, v. 36, p. 141-156.

Aumento, F., 1971. Uranium content of mid-oceanic basalts: Earth Planet. Sci. Lett., v. 11, p. 90-94.

Aumento, F., Mitchell, W.S., Fratta, M., Dostal, J., and Gustajtis, A., 1975. Interaction between sea water and oceanic layer 2 as a function of time and depth: Geol. Soc. Am., Abstracts with Programs, v. 7, p. 713.

Fisher, D.E., 1970. Homogenized fission track determination of uranium in whole rock geologic samples: Anal. Chem., v. 42 , p. $414-416$.

Flanagan, F.J., 1973. 1972 Values for international geochemical reference samples: Geochim. Cosmochim. Acta, v. 37, p. 1189-1200.

Henderson, P., Mackinnon, A., and Gale, N.H., 1971. The distribution of uranium in some basic igneous cumulates and its petrological significance: Geochim. Cosmochim. Acta, v. 35 , p. 917-925.

Kleeman, J.D. and Lovering, J.F., 1967. Uranium distribution in rocks by fission track registration in lexan plastic: Science, v. 156 , p. 512-513.

McIntire, W.L., 1963. Trace element partition coefficients a review of theory and applications to geology: Geochim. Cosmochim. Acta, v. 27, p. 1209-1264.

Mitchell, W.S. and Aumento, F., 1974. A geochemical comparison of minerals of oceanic and continental ultramafic origin: J. Geoph. Res., v. 79, p. 5529-5532.

1976. Fission track chronology and uranium content of basalts from DSDP Leg 34. In Hart, S.R., Yeats, R.S., et al., Initial Reports of the Deep Sea Drilling Project, Volume 34: Washington (U.S. Government Printing Office), p. 451-454.

Nishimura, S., 1972. Partition of uranium between peridotite nodules and host basalt: Chem. Geol., v. 10, p. 211-221.

Onuma, N., Higuchi, H., Wakita, H., and Nagasawa, H., 1968. Trace element partition between two pyroxenes and the host lava: Earth Planet Sci. Lett., v. 5, p. 47-51.

Philpotts, J.A. and Schnetzler, C.C., 1970. Phenocryst matrix partition coefficients for $\mathrm{K}, \mathrm{Rb}, \mathrm{Sr}$ and $\mathrm{Ba}$, with applications to anorthosite and basalt genesis: Geochim. Cosmochim. Acta, v. 34, p. 307-322.

Rodgers, J.J.W., and Adams, J.A.S., 1969. Uranium. In Wedepohl, K.H. (ed.), Handbook of geochemistry: Berlin (Springer-Verlag).

Seitz, M.G. and Hart, S.R., 1973. Uranium and boron distributions in some oceanic ultramafic rocks: Earth Planet. Sci. Lett., v. 21, p. 97-107. 
PLATE 1
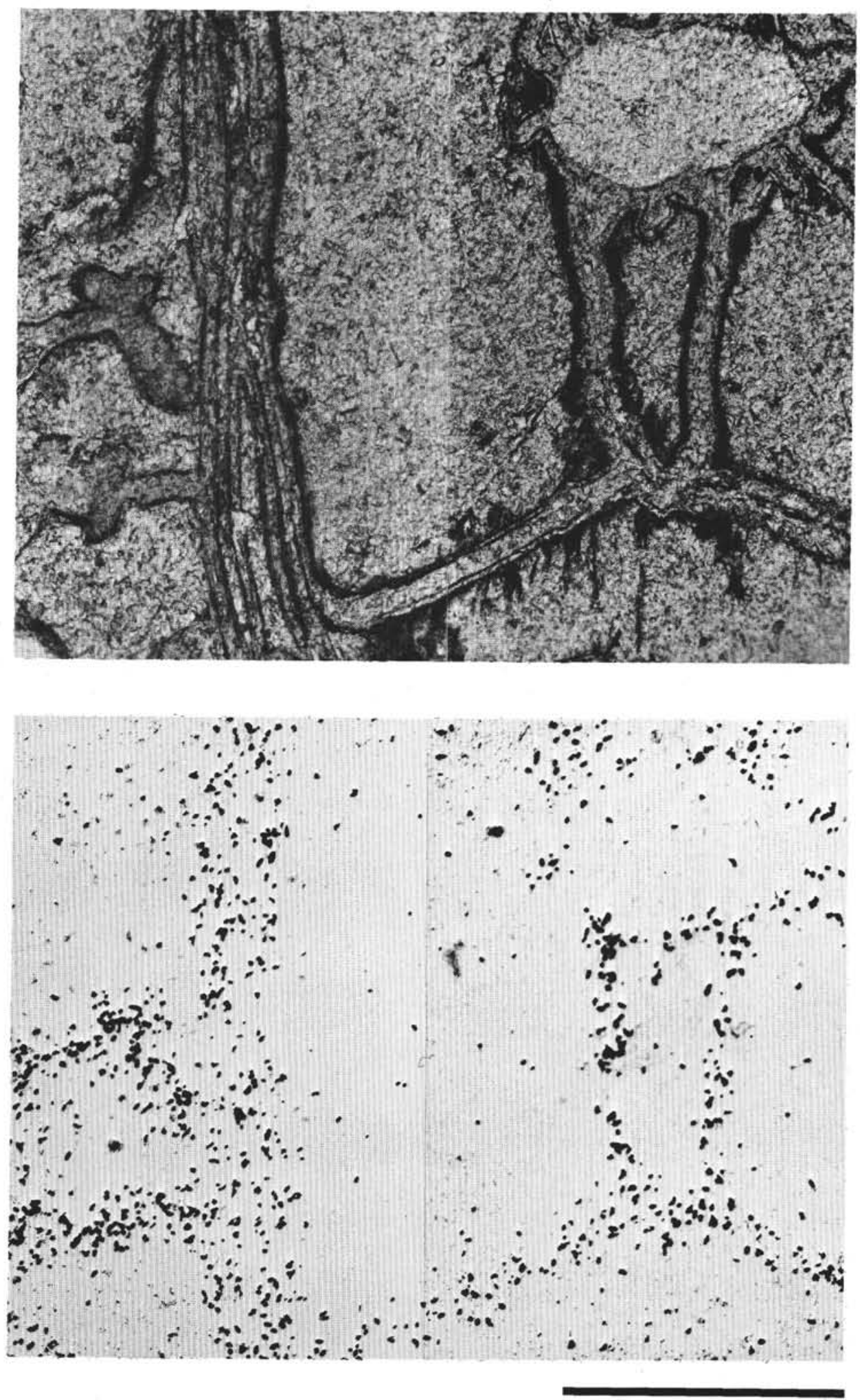

Distribution of uranium in sideromelane. Zones of palagonite surrounding the fresh glass are rich in uranium. The small rounded phenocryst at the top right of the illustration is plagioclase. Scale $\mathrm{bar}=500 \mu \mathrm{m}$. 
PLATE 2
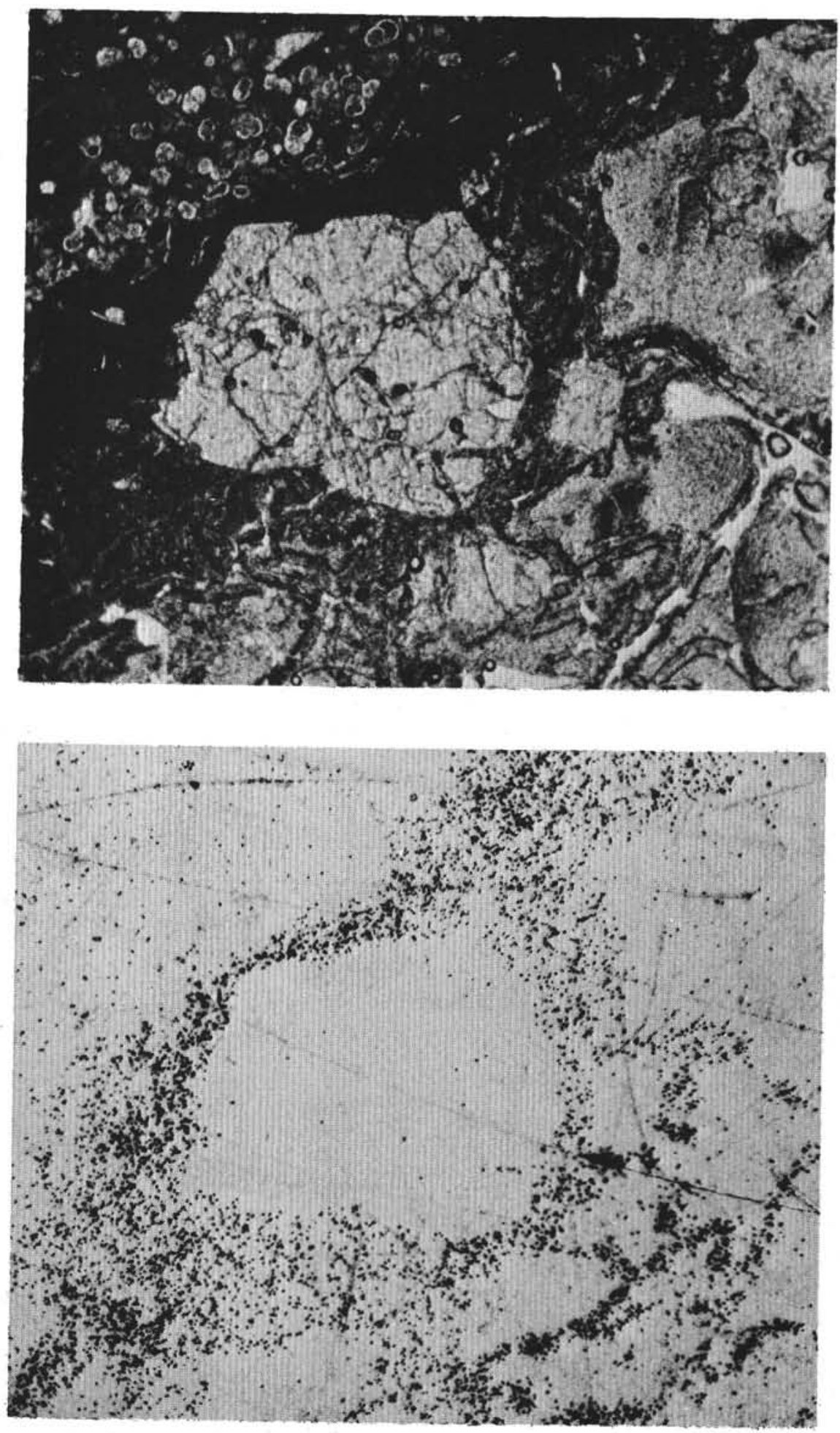

Distribution of uranium in a glassy basalt-sediment contact zone. Fragments of sideromelane are seen in the lower right of the illustration and a large plagioclase phenocryst is seen at center. Scale bar $=500 \mu \mathrm{m}$. 
PLATE 3
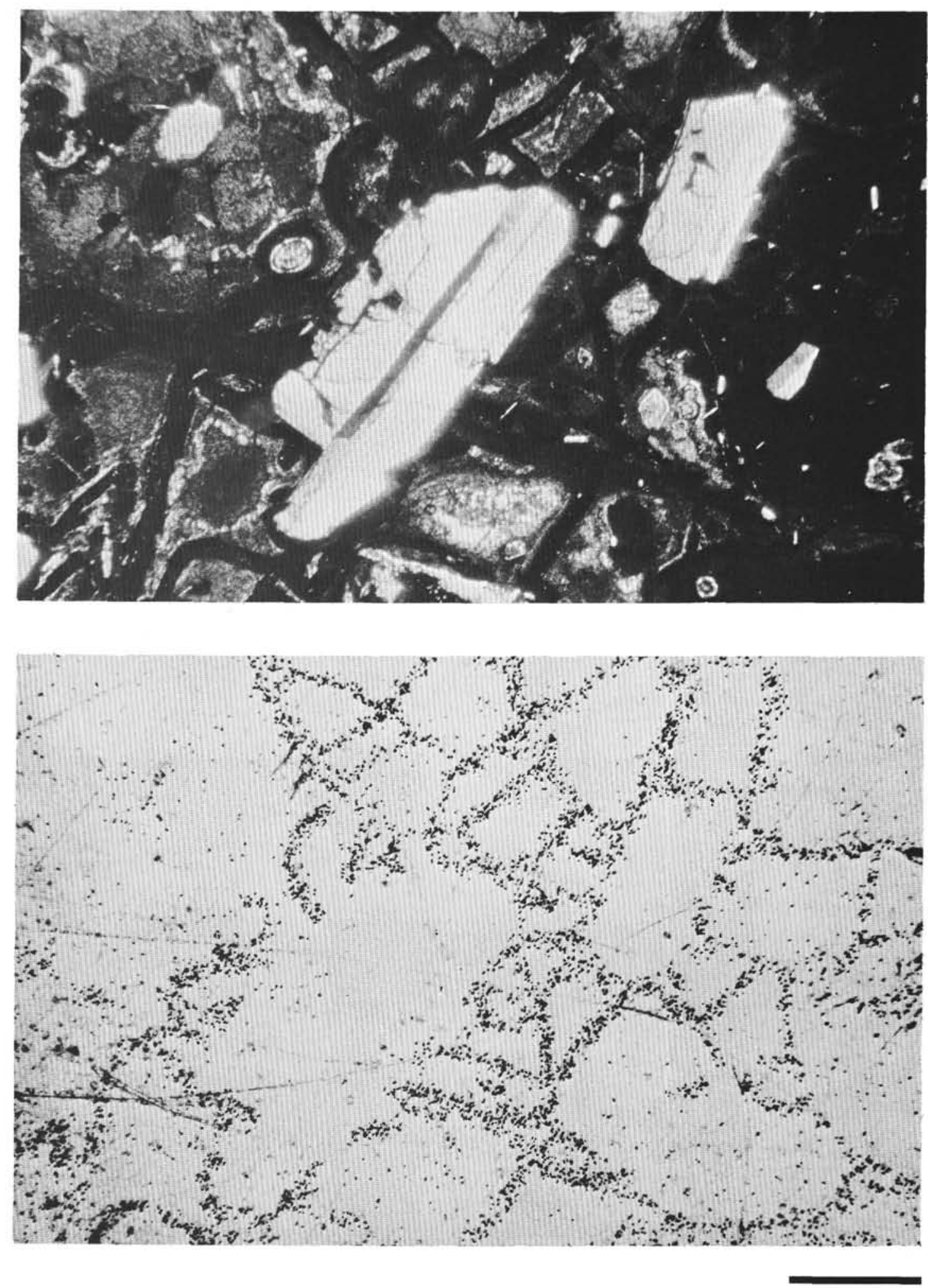

Distribution of uranium in a glassy basalt with phenocrysts of plagioclase. The uranium is concentrated in zones of palagonite. Scale bar $=500 \mu \mathrm{m}$. 
PLATE 4

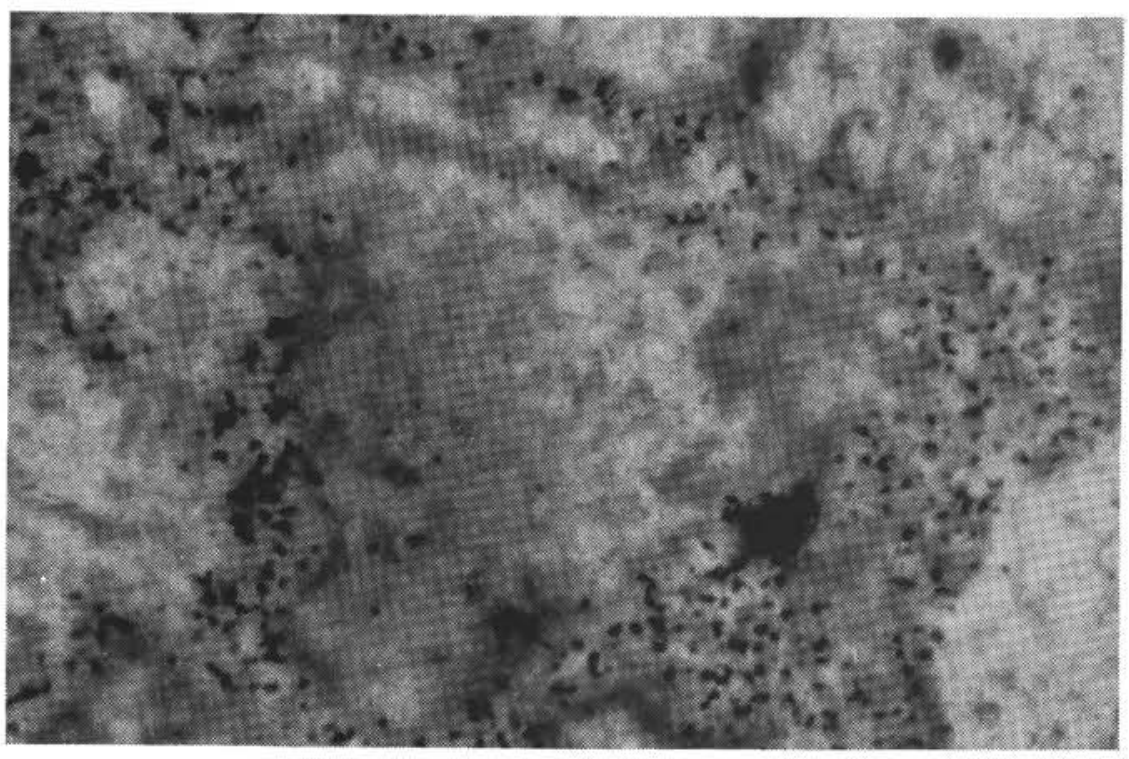

Distribution of uranium fission tracks in a detector placed over the rock slice. (See text.) Scale bar $=500 \mu \mathrm{m}$.

\section{PLATE 5}

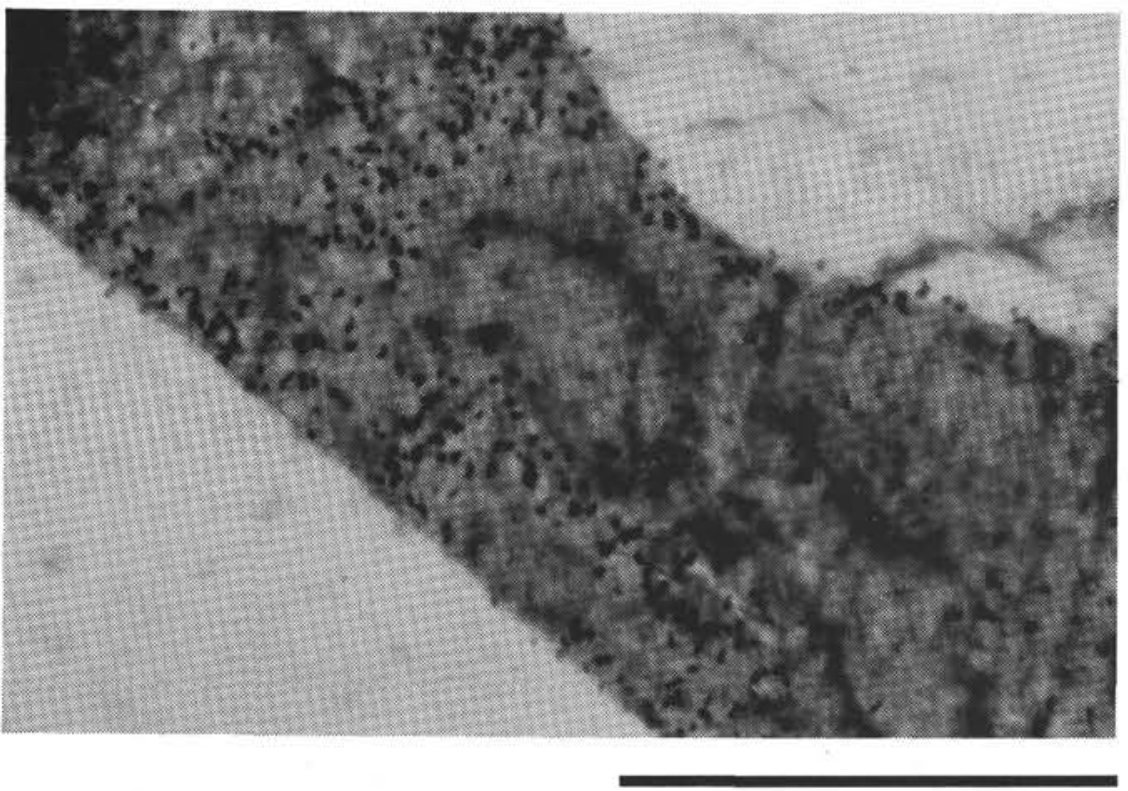

Distribution of uranium fission tracks in the detector placed over the rock slice. The light areas are plagioclase phenocrysts and the dark areas are devitrified and altered matrix. Scale bar $=500 \mu \mathrm{m}$. 